\title{
A Psycho-Pragmatic Study of Self-Identity of Kurdish EFL Learners in Kurdistan Region
}

\author{
Ayad Hameed Mahmood ${ }^{1} \&$ Zana Mahmood Hassan ${ }^{2}$ \\ ${ }^{1}$ English Department, College of Education, University of Diyala, Iraq \\ ${ }^{2}$ English Department, College of Languages, University of Sulaimani, Sulaimani, Iraq \\ Correspondence: Zana Mahmood Hassan, English Department, College of Languages, University of Sulaimani, \\ Sulaimani, Iraq. E-mail: zana.hassan@univsul.edu.iq
}

\author{
Received: October 25, 2017 Accepted: January 14, 2018 Online Published: January 16, 2018 \\ doi: 10.5539/elt.v11n2p99 URL: http://doi.org/10.5539/elt.v11n2p99
}

\begin{abstract}
This paper is an extract from a $\mathrm{PhD}$ dissertation on the impacts of learning English on the self-identity of Kurdish EFL learners. Language is a distinctive feature of human being. Similarly, identity is considered as a sign humans are recognized by. So, scrutinizing the relationship between these two related components of human life is revealing. Most of the research papers in this area focus on how language is used as a tool to express someone's identity. However, this research focuses on how the process of learning English makes possible changes, if any, in the learners' self-identity. A Likert-questionnaire of 30 questions is given to 150 EFL learners from three main universities to understand the differences that might happen in the learners' self-identity as a result of learning English. Finally, some conclusions are drawn based on the collected data and the references are documented.
\end{abstract}

Keywords: self-identity, language learning, Kurdish EFL learners, self-Identity change

\section{Introduction}

It is generally agreed upon that language is one way to express people's identities. These two terms seem to be interrelated in a somehow complicated way. Studying identity in relation to language is a contemporary field of study. Few researchers have touched upon studying the impact of learning English as Foreign Language (EFL henceforth) on learner's self-identity. Therefore, it is revealing to conduct an investigation into unpacking the impacts, if any, of learning English on Kurdish EFL learners' self-identities.

\subsection{Key Definitions}

The term psycho-pragmatics was coined by Dascal in a lecture he delivered in a conference in Tel Aviv in 1978/9. He states that he coined the word for 'the branch of pragmatics that deals not with the social uses of language such as communication (a task reserved for 'socio-pragmatics') but with the mental uses of language' (Dascal, 1983). Through this term, the connection between mental uses of language to express self-identity of foreign language learners in Kurdistan region, which is a major concern of this study, is investigated.

\subsubsection{Psychological Definitions}

Psychology is regarded as the first field of study that touched upon the issue of identity at modern time. Erik Erikson is believed to be a pioneer in discussing the issue of adolescents' identity and the concept of 'identity crisis'. To Erikson (1950 \& 1963), identity 'is a feeling based on two observations: the observation of a consistency and continuity of the self, and the observation, that others recognize this continuity and consistency too.' Psychologically, Erikson connects identity to the 'consistency and continuity of the self' as well as other's recognition of that sense. Similarly, Katzenstein (1996) defines identity as 'references mutually constructed and evolving images of self and other.' Here, the emphasis is on the images of both the 'self' and the 'other' in terms of explaining what identity is.

According to Sherif (1982), identity is 'the individual's psychological relationship to social category systems.' Moreover, McAdams (1995) argues that identity is 'a unified, purposeful aspect of self and hence is only part of the self-concept.' These two definitions stress the psychological aspect of an individual's feelings, either to a social system or his/her image of the 'self'. 


\subsubsection{Pragmatic Definitions}

Defining identity from a pragmatic perspective is somehow challenging. A major reason is that the study between language use in context, which is pragmatics, and identity from a scholarly linguistic viewpoint is not an obvious area in itself. Carr-Chellman and Levitan (2016) argue that to understand identity from a pragmatic standing point is to look at '...identity as relational, multifaceted, and holistic concept that runs through an individual." They maintain that looking at identity from a pragmatic perspective would provide answers to these vital questions such as whether one can have one or more than one identity, or is identity static or changeable, or do identities pre-exist or people build them over time.

One major area in which the relationship between these two concepts, viz. pragmatics and identity, can be seen is looking at the process of language learning process as part of an individual experience. The more we know about ourselves and about the world around us, the more we become aware of our identity (Peirce, 1995). To show the strong connection between pragmatics and identity, linguistics show their relationship in a theory called 'Pragmatic Identity Theory' which is rooted in a wider school known as 'American Pragmatism' (Carr-Chellman \& Levitan, 2016).

\subsection{Self and Identity}

In common usage, the term 'self' is used to denote anything about an individual. This includes both terms: 'I' as an actor who does something as well as the term 'me' as an object that something has been done to (Oyserman, Bybee, Terry, \& Hart-Johnson, 2004). Therefore, in modern psychology, this term is used as an umbrella word to reference both 'I' and 'me'.

The study of 'self' and 'identity' can be traced back to James (1890) in his research in social psychology. Back then, the term 'self' was used to mean 'self-reflection' and the term identity as 'one's behavior' (Owens, 2006). However, as a scholarly field of study, the investigations into the relationship between self and identity started in the mid of $20^{\text {th }}$ century with Erikson's study on identity crisis of adolescence. Through reading the literature, it can be stated that there is a fluctuation in understanding the term. Studying the meaning of 'self' was somehow ignored until 1950s (Swann \& Bosson, 2010). Sociologists and social psychologists revived studying the meaning of 'self' pioneered by Goffman (1959). The study of 'self' in its original sense gained attention from 1972 onwards more than ever before (Swann, 2005).

Despite the fact that James (1890, p. 330, cited in Owens, 2006) states that defining selfhood is 'the most puzzling puzzle with which psychology has to deal with.' There has been many papers to describe the meaning of 'self' from a psychological point of view. To start with the term 'self', Owens (2006, p. 206) provides a compelling, yet complex, definition of the term self as 'a process and organization born of self-reflection'. Here, the focus has been put on how one perceives him/herself is what is known as 'self' to that person

As for the relationship between 'self' and 'identity', it has been generally accepted that James (1890) established a base on which the relationship between the two terms seem to be in complementary. James (1890) argues that one person may have many positions and titles within the society, which respond to the concept of 'selfhood' This is exactly where identities enter to the world of 'selfhood' (Stets \& Burke, 2003). According to Burke (1980, p. 30), who defines identity as 'an internalized positional designation', the overall image of 'selfhood' consists of multiple identities depending on the position of the person in the society. Therefore, it can be understood that identities are the roles that an individual may have in the society.

\subsection{Theories of Identity}

There are different ways to approach the issue of identity. Due to the nature of this study, two major aspects of identity, which are psychology and pragmatics, are focused on in the coming section.

\subsubsection{Psychological Identity Theory}

For psychologists, identity is 'a set of behaviors, emotions, and thought patterns that are unique to an individual' (Peck, 1997). Moreover, the famous German psychologist, Peter Weinreich (1939-2016) defines identity as 'the totality of one's self-construal, in which how one construes oneself in the present expresses the continuity between how one construes oneself as one was in the past and how one construes oneself as one aspires to be in the future' (Weinreich, 1986). It can be understood that identity is how one defines him/herself. This definition may be related to past, present or future.

Psychological theories of identity typically differentiate between an individual's identity (personal identity) and group or collective identity (social identity) (Spencer-Oatey, 2007). For psychologists, individual identity refers to how someone defines him/herself as a unique person, whereas collective identity or social identity is meant to 
be how someone describes him/herself as a member of a group (Spencer-Oatey, 2007). One has to bear in mind that the description of one's individual identity with the same person's collective identity may sometimes overlap.

To understand the psychological aspect of identity, one has to outline how psychologists approached this issue. The first thing to bear in mind is the difference in the terminology to describe the same idea. For North-American psychologists (e.g. Markus, 1977), the term 'self' has been used to describe the features of an individual. Therefore, for them, self is more individualistic in a way that it focuses more on one's personal attributes.

On the other hand, European psychologists and social psychologists (Tajfel \& Truner, 1979) tend to use the term 'identity' in a more common way in comparison with the term 'self'. This emphasis can be related to their belief of the role of the group membership and the social dimension of the person rather than the interpersonal feeling of the individual (Simon, 2004).

\subsubsection{Pragmatic Identity Theory}

It can be stated that pragmatic identity theory, or understanding identity from a pragmatic standpoint, can be traced back to the school of American pragmatism (Carr-Chellman \& Levitan, 2016). American pragmatists maintain that '.. identity (or self-concept), like everything in human experience, is contingent, relational, and in constant process' (Carr-Chellman \& Levitan, 2016, p. 3). This gives the impression that pragmatists see identity to be in continuous construction and subject to change.

Carr-Chellman and Levitan (2016) argue that Pragmatic Identity Theory is another important gate through which we can understand the concept of identity. The two conventional, and probably most common, ways to explain identity have been from either a psychological standpoint or a sociological perspective. However, according to Carr-Chellman and Levitan (2016) a third way, which is based on Dubios and Vygotsky along with the viewpoints of American pragmatists, is quite possible. This is where Pragmatic Identity Theory comes in to explain identity from a pragmatic point of view.

Pragmatic Identity Theory comes to existence when a third option is quite likely, other than the psychological or sociological analysis of identity. Pragmatic Identity Theory looks at identity as 'an integrated, dynamic conceptual framework, effectively bridging the social and internal origins of identity' (Carr-Chellman \& Levitan, 2016, p. 4). Pragmatic Identity theory looks at identity developments as a learning process.

The basic pillar of Pragmatic Identity Theory, according to Carr-Chellman and Levitan, (2016), is that identities are in 'complex relationships'. The complexity is both inside one person with the outside the world. One has to bear in mind that based on Pragmatic Identity theory relation is very important emotionally, cognitively and physically. That is probably why this theory can be regarded as a bridge between a pure psychological view and a pure sociological view of identity.

Based on Pragmatic Identity Theory, identities are regarded as 'a plastic (in the sense of malleable but not fluid) and semi-explicit part of experience that touches all aspects of human life' (Carr-Chellman \& Levitan, 2016). It can be understood that identity, for pragmatic identity theorists, is a mixture of two parts in anyone's life. One part is affected, constructed, reshaped and changed in an individual's life. The other part is fixed in anyone's life; things that are unseen and kept personal to any individual.

According to Carr-Chellman and Levitan (2016), Pragmatic Identity theory is based on the following four major premises:

1) Identity is constructed through the synthesis of three influences: a) self-concept, b) the responsive subconscious, and c) societal meanings or the collective understandings of identity.

Based on this premise, identities are the result of these three influences. It should be mentioned that the order is subject to change. Carr-Chellman and Levitan (2016) argue that self-concept 'is learned overtime'. Self-concept does not only mean understanding ourselves, but it may be part of what we own, possess or the feelings that we have.

The second impact on identity is the responsive subconscious, which is the part of the identity that defines who we are and we come to know it every now and then (Carr-Chellman \& Levitan, 2016). It is like an inner voice that tells us what we have to do and how we should do it.

The third influence is the role of the society in shaping one's identity. Carr-Chellman and Levitan (2016) maintain that we cannot discuss identity in isolation. As long as humans live inside a group of people, the culture and the societal view plays some role in the identity of the individuals. This is a major focus of the social identity 
theory.

2) An individual's identity is made up of many sub-identities that have different levels of salience, prevalence, and longevity that manifest in different contexts (Stets \& Serpe, 2013).

The second premise for identity, based on pragmatic identity theory, focuses on the concept of identity itself. The identity consists of multiple 'sub-identities' which are different depending on time and situation. According to the above-mentioned premise, the level, the accessibility and the length of a sub-identity vary from one context to another. To explain it, one may claim a certain identity in a specific situation, but the same person may claim a different one in another context.

3) Inherent in identity is an emotional affect and physical embodiment. The value individuals and others place (or do not place) on the characteristics that make up their sub-identities affect individuals' self-concept, efficacy, mobility, access to social goods, and overall wellbeing.

Based on this premise, it is almost impossible to separate identity from emotions or the other way around. Carr-Chellman and Levitan (2016) argue for the central role of emotions in the influence they have on sub-identities and consequently they influence self-identity. Due to a certain emotional reaction, one may claim his identity to be attached with or similar to a certain group for quite some time.

4) Identities and Identity values can be fluid, but certain parts of identity are stable and difficult to change.

Based on Carr-Chellman and Levitan's (2016) interpretation of this premise, each person has what they call 'identity value', which is the values one has for him/herself, and identity. Certain parts of identity, which are known as master identity and personal identity (which will be explained in 2.8), are very difficult to change, whereas there are other parts, such as the social part, that are flexible and changeable based on time and context.

As a result, it can be argued that pragmatic identity theory attempts to show the explicit as well as implicit part of identity. That is why this approach is used in this study to reveal the influence of learning a new language on the self-identity of the EFL learners.

\subsection{Language and Identity}

Tabouret-Keller (1998) argues that there is a strong relationship between language and identity in a way that sometimes a single feature, such as accent, is enough to show the identity of an individual. In order to investigate the relationship between language and identity, it is important to investigate how scholars make this connection. Many experts in the field have defined language in relation to identity. One definition is given by Spolsky (1999) who states 'language is a central feature of human identity'. When we hear someone speaks, we immediately make guesses about his/her gender, education level, age, profession, and place of origin. Beyond this individual matter, language can be regarded as a powerful symbol of national and ethnic identity in the group or collective level (Spolsky, 1999, p. 181). It is interesting here to see how language is considered as the 'central feature' of identity

It is generally accepted that there is a close relationship between language and identity. For some scholars, language is considered as an important tool to express the identity of an individual (Rovira, 2008). Furthermore, Ochs and Schieffelin (2008) concur with the previous statement by saying that 'language is the main vehicle of expressing the self'. In the group level, language is considered as an indicator of the identity of a group (Hozhabrossadat, 2015).

\subsection{Foreign Language Learning and Self-Identity}

Initially, the investigation into the relationship between language and identity was mainly concerned about the second language learners who live in countries where the language is largely used (Tylor, Busse, Gagova, Marsden, \& Roosken, 2013). Norton (1972, also known as Peirce) is regarded as the first scholar in the area of second language acquisition to investigate the relationship between language learning and identity (Sacchi, 2014). For her, learning a new language is not just communicating in another language, but it is a continuous arrangement and rearrangement of who the learners are and how they can relate themselves to the people around them. In other words, language learners construct a new identity when they learn a new language (Norton, 1997). Furthermore, Lightbown and Spada (2006) argue that learning a new language means learning a new identity.

Lambert (1972) is considered as a prominent scholar who investigates the relationship between learning a foreign language and the self-identity of the language learner. He focuses on the role of motivation in learning a foreign language which consequently will affect the self-identity of the learner (Lambert, 1981). Lambert established a model known as socio-psychological identity model. In this model, Lambert asserts that the learners who successfully acquire a second language will change some behavior to show their connection to the 
foreign language group and their culture (Gao, Zhao, Cheng, \& Zhou, 2007).

Based on Lambert's (1972) socio-psychological model learning a foreign language will ultimately make some changes in the identity of the language learner. It is important to notice that these changes happen due to social as well as psychological factors.

\subsection{Types of Language Learners' Self-Identities}

As stated earlier, EFL learners are divided into some categories regarding the changes that might happen with their self-identities based on Lambert's (1972) socio-psychological identity model and Gao's (1997) classification for changing self-identities. It is true that Gao's categorization classifies learners into five major types. However, a new classification can be given under somewhat more general headings to combine those categories that are related. In this study, EFL learners are divided into three categories: learners whose identities are changed, learners who feel that they have a spilt identity and those learners who do not feel any change in their self-identity due to learning a foreign language.

\subsubsection{Change in Learner's Self-Identity}

Gao et al. (2007), Boonchum (2010) and Zare-ee and Asgari Matin's (2014) studies of EFL learners confirm that many learners feel that their self-identities have changed due to learning English. It is worth mentioning that Gao et al.'s study investigated Chinese learners, Boonchum's study investigated Thai EFL learners and Zare-ee and Asgari Matin's (2014) study was conducted on Persian learners. All confirmed that learning English has changed the self-identities of many EFL learners. Interestingly, all studies report a significant change in the self-confidence of EFL learners because of learning English. Participants state that they feel more confident after learning English.

Many studies (e.g., Boonchum, 2010; Gao et al., 2007; Zare-ee \& Asgari Matin, 2014) show a strong relationship between self-identity and self-confidence. They argue that a better self-confidence will affect the self-image of the person and consequently this affects the self-identity of the learners. It is interesting to know whether or not Kurdish EFL learner will have the same feeling about changing their self-confidence due to learning English.

Another area of change in the self-identity of EFL learners is their attitudes. Learners reported that they feel that their attitudes have changed after learning English. For instance, Persian learners say that now they have a more positive view about women's rights. Some learners say that they are influenced by English; they see women differently (Zare-ee \& Asgari Matin, 2014). Chinese learners feel more open to differences in comparison with their attitudes before learning English (Gao et al., 2007). Thai learners report that part of their behavior changed after learning English (Boonchum, 2010). Almost all participants have had a positive view on English say that they have been influenced more due to learning it. Regarding Kurdish EFL learners, it seems necessary to find out to what extent their attitudes have changed after learning English.

It has to be mentioned that there are so many socio-biological factors behind this change of self-identity of EFL learners in these studies (Boonchum, 2010; Gao et al., 2007; Zare-ee \& Asgari Matin, 2014). Gender, for instance, is an important factor. Male participants seem to be more flexible and open to change because of learning English in comparison with female participants. One reason could be the society's view on female in these places. For instance, Persian female participants report that it is very challenging for them to act upon their new beliefs that they have after learning English because of the social restrictions on them (Zare-ee \& Asgari Matin, 2014). Therefore, even if any change occurs in the self-identity of EFL learners, they might not be able to reflect on them because of the social or biological restrictions.

One should bear in mind that these studies did not follow a pure psychological or pragmatic approach in their investigation. Therefore, one should expect some different results, as well as few similarities, of this current study in comparison with those previously conducted.

\subsubsection{Division in Learner's Self-Identity}

After learning a new language, some learner's self-identities split between their real community and their imagined community. One way in which this split can be realized is through uttering native language words while speaking with English (Teer, 2013). Many researchers (e.g. Gao et al., 2007, Boonchum, 2010) argue that this stage could be temporary as learners develop in their learning process. However, for some learner, this division continues even after learning the language. One reason could be learner's hesitation as to follow which cultural norms in his/her society (Zare-ee \& Asgari Matin, 2014).

It can be said that religious background is another factor of creating this division in the self-identity of EFL 
learners. For example, Persian learners who come from more religiously or socially conservative places find it very hard to switch between their identities when using the foreign language (Zare-ee \& Asgari Matin, 2014).

It should be mentioned that the number of those learners who feel this split in their self-identity is fewer in comparison with others who feel that their self-identity have changed after learning English in China, Japan, Thailand and Iran (Gao et al., 2007; Teer, 2013; Zare-ee \& Asgari Matin, 2014). It is revealing to find out whether or not Kurdish EFL learners experience this division in their self-identities due to learning English.

\subsubsection{No change in Learner's Self- Identity}

The third group of language learners are called resistant learners. They are those learners who do not feel any change in their self-identity even after learning a new language because they think that learning a new language is not related to changes in self-identity (Teer, 2013). For these learners, it is impossible to turn into someone else because of learning a new language (Gao et al., 2007).

Regarding the reasons that might lead to no change in self-identity, language proficiency is regarded as one of them. Zare-ee and Asgari Matin (2014) report that the vast majority of those EFL learners who state that they have not been changed in any way due to learning English are low level learners. They argue that less proficient EFL learners struggle to understand English culture, and possibly be affected by it.

The personality of the learner is believed to be another factor for this no change in the self-identity. Boonchum (2010) argues that those Thai learners who communicate more with English native speakers will be more open to change. However, those learners who hardly or never communicate with native speakers are less likely to be affected by learning English.

It should be mentioned that generally the number of EFL learners who fall into this category are the least in comparison with the two previously mentioned categories. This number remains to be checked and compared with other categories in relation to Kurdish EFL learners.

\section{Methodology}

This section is devoted to the methodology followed for this paper. It includes sampling and data collection tools. Then data analysis method has been explained.

\subsection{Sampling and Data Collection Tools}

This study targets Kurdish EFL learners at undergraduate level who have studied English for more than ten years prior to college. At college, they are all majors in English and study both English language and literature. There were 150 respondents to the questionnaire who voluntarily participated in the data collection. They are from three major universities in the region: University of Sulaimani, University of Salahaddin and University of Duhok. The questionnaire consists of 30 questions in the form of a Likert Questionnaire.

\subsection{Data Analysis Method}

The method used for data analysis involves dividing the questions into four variables. The first one is the learner's motivation to learn and/or study English. The second variable is those learners whose self-identity is changed due to learning English. The third variable is those learners who do not feel any change in their self-identity as a result of learning English. Finally, the fourth variable is those learners who feel that they have a divided identity since learning English. A specialised program is used for data analysis which is done by an expert in the field of data analysis.

\subsection{The Selected Model for Data Analysis}

As this study tackles the pragmatic and psychological aspect of self-identity, all the questions are set based on the major premises of Pragmatic Identity Theory by Carr-Chellman and Levitan (2016) and Identity Structure Analysis by Weinreich (1986). The details of both these theories are discussed in the extended version of this study.

\section{Data Analysis}

The first step of data analysis is to check the efficiency and reliability of the collected data. Based on the instructions of the statistical program, which is called JMP version 13.1, typically if the data ranges between 0.6 to 0.7 , it is considered as acceptable and efficient for scientific purposes. 


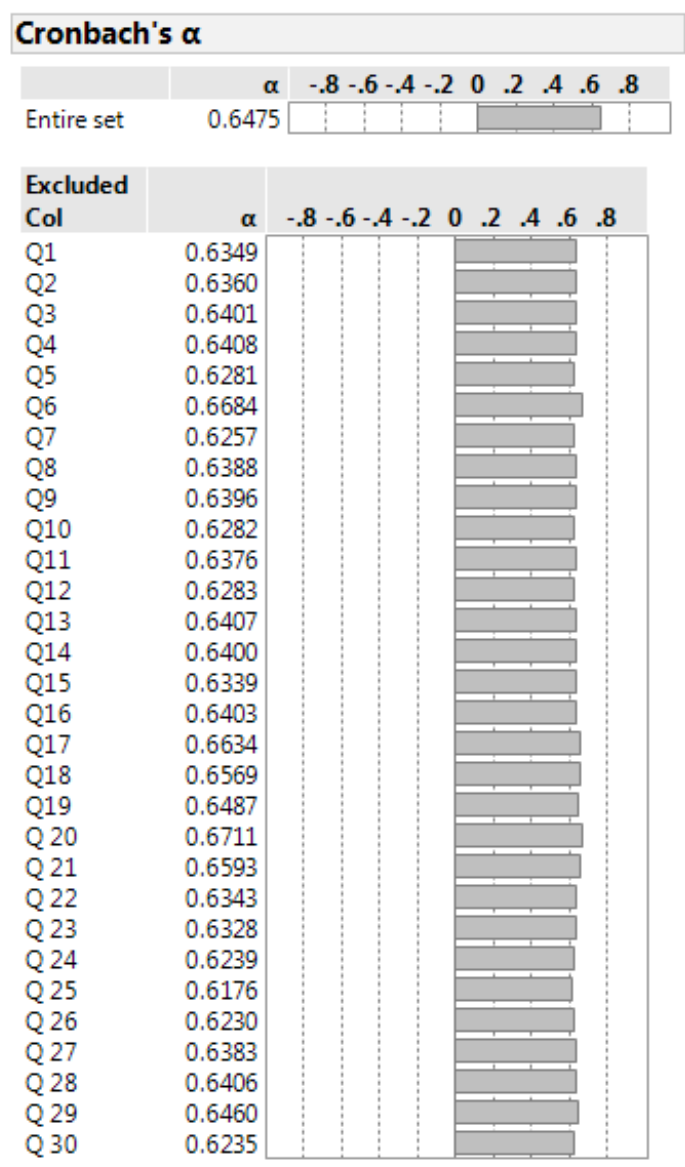

Plot 1 . The value of the reliability and co-efficiency of the collected data

Based on Plot 1 the data seems to be reliable and efficient for all study variables as it lies between the acceptable scope, and the data is possible for statistical analysis and scientific research.

The main purpose of this section is to deal with the details of data presented by a questionnaire and its analysis regarding learning English and its impact on the self-identity of EFL learners in Kurdistan. For the sake of data analysis, the questionnaire is divided into four main variables, a dependent variable (Motivation to Learn English), and three independent variables (Change in the Self-Identity of the Learner, No Change in the Self-Identity of the Learner, and Division in the Self-Identity of the Learner).

A five point Likert-type scale was used for rating the answers of the questions in which 1 is used to show Strongly Agree to the lowest weight which is giving 5 to Disagree, and between them there are three other weights (give 2 to Agree, give 3 to I do not Know, and give 4 to Strongly Disagree). The reason why the rating is done in this way is intentional as it will prevent learners from giving the same number to all questions. This will make the respondents to read every question as some of them contradict others. Based on the results, the values of the arithmetic averages reached by the study will be solved to interpret the data as follows:

Table 1. The range of the mean for each point

\begin{tabular}{cccc}
\hline $\begin{array}{c}\text { High Level } \\
\text { Agreement }\end{array}$ & $\begin{array}{c}\text { Moderate Level } \\
\text { Agreement }\end{array}$ & $\begin{array}{c}\text { High Level } \\
\text { Disagreement }\end{array}$ & $\begin{array}{c}\text { Moderate Level } \\
\text { Disagreement }\end{array}$ \\
\hline $1 \leq \mu \leq 2$ & $2<\mu \leq 3$ & $3<\mu \leq 4$ & $4<\mu \leq 5$ \\
\hline
\end{tabular}

The above table shows the range for each point in the questionnaire. If the mean of the answer lies between 1 and 2, it is understood to be in high agreement with the question. It should be mentioned that the mean is considered as the average as 'mean' is a statistical term. 
As it has been stated earlier, the data analysis started with analyzing the questions individually and then the correlations between the variables are presented. After that, the impact of each variable on the other has been analyzed and discussed.

\subsection{Change in the Self-Identity of the Learner}

Table 2. Statistical analysis for independent variable change in the self-identity of the learner

\begin{tabular}{|c|c|c|c|c|c|c|c|c|c|c|}
\hline \multirow[b]{2}{*}{ Variables } & \multirow[b]{2}{*}{ Sections } & \multicolumn{5}{|c|}{$\begin{array}{c}\text { Answers of Sample } \\
\text { Members }\end{array}$} & \multicolumn{4}{|c|}{ Statistical Indicators } \\
\hline & & 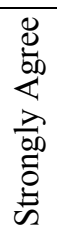 & $\begin{array}{l}\stackrel{8}{\leftrightarrows} \\
\stackrel{5}{4}\end{array}$ & $\begin{array}{l}3 \\
0 \\
0 \\
0 \\
0 \\
0 \\
0 \\
0\end{array}$ & 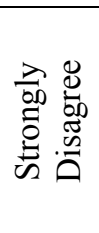 & 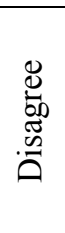 & 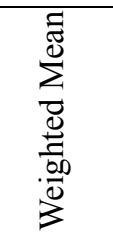 & 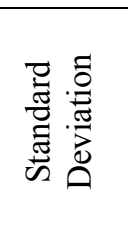 & 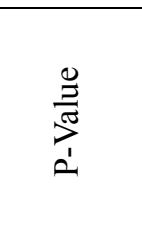 & $\begin{array}{l}\tilde{y} \\
\tilde{\Xi} \\
\tilde{\approx}\end{array}$ \\
\hline \multirow{8}{*}{ 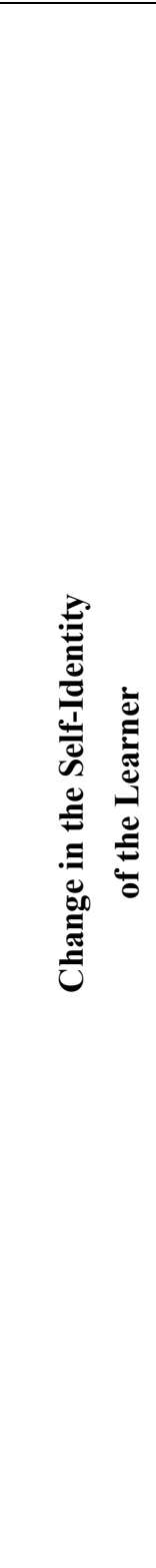 } & $\begin{array}{l}\text { I have, somehow, two } \\
\text { different personalities } \\
\text { after learning English. }\end{array}$ & 42 & 61 & 27 & 7 & 13 & 2.2533 & 1.1712 & $<.0001^{*}$ & 2 \\
\hline & $\begin{array}{c}\text { I can express my ideas } \\
\text { and talk about my } \\
\text { feelings better in } \\
\text { English. }\end{array}$ & 27 & 54 & 42 & 11 & 16 & 2.5667 & 1.1839 & $<.0001^{*}$ & 6 \\
\hline & $\begin{array}{l}\text { When I speak English, } \\
\text { I believe I am thinking } \\
\text { differently. }\end{array}$ & 30 & 66 & 31 & 6 & 17 & 2.4267 & 1.1891 & $<.0001^{*}$ & 5 \\
\hline & $\begin{array}{l}\text { I can express my } \\
\text { opinions better by } \\
\text { using English rather } \\
\text { than Kurdish. }\end{array}$ & 17 & 44 & 30 & 19 & 40 & 3.1400 & 1.3904 & $<.0001^{*}$ & 14 \\
\hline & $\begin{array}{l}\text { When speaking with } \\
\text { my classmates, I prefer } \\
\text { to use English for } \\
\text { interaction. }\end{array}$ & 25 & 63 & 33 & 10 & 19 & 2.5667 & 1.2174 & $<.0001^{*}$ & 6 \\
\hline & $\begin{array}{l}\text { I think learning English } \\
\text { has been a new } \\
\text { experience which has } \\
\text { affected my entire life }\end{array}$ & 49 & 65 & 21 & 4 & 11 & 2.0867 & 1.1109 & $<.0001^{*}$ & 1 \\
\hline & $\begin{array}{l}\text { After learning English, } \\
\text { I began to reject some } \\
\text { ideas, such as my } \\
\text { opinion about the } \\
\text { equality between man } \\
\text { and women }\end{array}$ & 31 & 42 & 33 & 20 & 24 & 2.7600 & 1.3545 & $<.0001 *$ & 11 \\
\hline & $\begin{array}{l}\text { It is somehow } \\
\text { challenging for me to } \\
\text { agree on many cultural } \\
\text { norms in Kurdish } \\
\text { society after learning } \\
\text { English such as } \\
\text { arranged marriage }\end{array}$ & 12 & 60 & 49 & 18 & 11 & 2.7067 & 1.0268 & $<.0001^{*}$ & 8 \\
\hline
\end{tabular}




\begin{tabular}{|c|c|c|c|c|c|c|c|c|c|}
\hline $\begin{array}{l}\text { After learning English, } \\
\text { I take some issues such } \\
\text { as Global Warming } \\
\text { more seriously }\end{array}$ & 20 & 52 & 52 & 8 & 18 & 2.6800 & 1.1488 & $<.0001^{*}$ & 7 \\
\hline $\begin{array}{c}\text { I believe learning } \\
\text { English gives me a new } \\
\text { identity in a sense that } \\
\text { I have a different } \\
\text { opinion about myself. }\end{array}$ & 32 & 70 & 29 & 8 & 11 & 2.3067 & 1.0927 & $<.0001^{*}$ & 3 \\
\hline $\begin{array}{l}\text { I feel I am socially } \\
\text { more attached to } \\
\text { English society after } \\
\text { learning English. }\end{array}$ & 40 & 63 & 24 & 5 & 18 & 2.3200 & 1.2442 & $<.0001^{*}$ & 4 \\
\hline
\end{tabular}

\begin{tabular}{|c|c|c|c|c|c|c|c|c|c|}
\hline $\begin{array}{l}\text { I think the more I learn } \\
\text { English language and } \\
\text { know about English } \\
\text { culture, the more I feel } \\
\text { a change in my } \\
\text { personality. }\end{array}$ & 24 & 63 & 22 & 15 & 26 & 2.7067 & 1.3338 & $<.0001^{*}$ & 8 \\
\hline $\begin{array}{l}\text { I think even if I speak } \\
\text { in Kurdish, my } \\
\text { personality and } \\
\text { behaviors change after } \\
\text { learning English. }\end{array}$ & 19 & 57 & 24 & 11 & 39 & 2.9600 & 1.4184 & $<.0001^{*}$ & 13 \\
\hline $\begin{array}{l}\text { It is easy for me to } \\
\text { convert (change) my } \\
\text { thoughts and behaviors } \\
\text { when I speak English. }\end{array}$ & 22 & 56 & 34 & 19 & 19 & 2.7133 & 1.2334 & $<.0001^{*}$ & 9 \\
\hline $\begin{array}{c}\text { I find it more } \\
\text { comfortable to speak } \\
\text { about socially sensitive } \\
\text { issues such as } \\
\text { homosexuality using } \\
\text { English rather than } \\
\text { Kurdish. }\end{array}$ & 33 & 60 & 31 & 12 & 14 & 2.4267 & 1.1891 & $<.0001^{*}$ & 5 \\
\hline $\begin{array}{l}\text { I think learning English } \\
\text { has affected my } \\
\text { religious beliefs in a } \\
\text { sense that I am more } \\
\text { open to communicate } \\
\text { with people from a } \\
\text { different religion }\end{array}$ & 28 & 44 & 28 & 21 & 29 & 2.8600 & 1.3952 & $<.0001^{*}$ & 12 \\
\hline $\begin{array}{l}\text { I believe I am more } \\
\text { aware of political } \\
\text { issues and my political } \\
\text { views have changed as } \\
\text { a result of learning } \\
\text { English }\end{array}$ & 24 & 54 & 30 & 20 & 22 & 2.7467 & 1.2911 & $<.0001^{*}$ & 10 \\
\hline
\end{tabular}

Results of the Table 2 illustrate the following outcomes:

1). The arithmetic mean and its ranking of the question "I think learning English has been a new experience which has affected my entire life" is in the first-place of agreement by the sample members, in which the mean is 
2.0867, standard deviation 1.1109, and its $p$-value $=0.0001$ less than $\alpha=0.05$. This means that students agree with the content of this question with a moderate degree of the positive direction. In other words, English language has affected the entire life and it has been as a new experience for the students.

2). The arithmetic mean and its ranking of the question "I have, somehow, two different personalities after learning English" is in the second-place of agreement by the sample members, in which the mean is 2.2533 , standard deviation 1.1712, and its $p$-value $=0.0001$ less than $\alpha=0.05$, indicating that students agree with the content of this question with a moderate degree of the positive direction. In some way, students believe that they have two different characters after learning English.

3). The arithmetic mean and its ranking of the question relating to "I believe learning English gives me a new identity in a sense" is in the third -place of agreement by the sample members, in which the mean is 2.3067 , standard deviation 1.0927, and its $p$-value $=0.0001$ less than $\alpha=0.05$, Indicating that students agree with the content of this question with a moderate degree of the positive direction. That means, English language provides a new identity to the learner.

4). The arithmetic mean and its ranking of the question relating to "I feel I am socially more attached to English society after learning English" is in the fourth -place of agreement by the sample members, in which the mean is 2.3200, standard deviation 1.2442 and its $p$-value $=0.0001$ less than $\alpha=0.05$, Indicating that students agree with the content of this question with a moderate degree of the positive direction. Therefore, English language is a great link to connect the English communities.

5). The arithmetic mean and its ranking of the questions relating to "When I speak English, I believe I am thinking differently" and "I find it more comfortable to speak about socially sensitive issues such as homosexuality using English rather than Kurdish" are in the fifth -place of agreement by the sample members, in which the means of both questions 2.4267, standard deviations 1.1891 and their $p$-value $=0.0001$ less than $\alpha=0.05$, Indicating that students agree with the content of these questions with a moderate degree of the positive direction. In some other words, English Language makes people having different ideas, and provides more comfortable to speak on the sensitive matters of the communities compare to Kurdish language.

6). The arithmetic mean and its ranking of the questions relating to "I can express my ideas and talk about my feelings better in English" and "When speaking with my classmates, I prefer to use English for interaction" are in the sixth -place of agreement by the sample members, in which the means are 2.5667, standard deviations $(1.1839,1.2174)$ respectively, and their $p$-value $=0.0001$ less than $\alpha=0.05$, Indicating that students agree with the content of these questions with a moderate degree of the positive direction. In some other words, students believe that English is an easier language to express the ideas and interact with others.

Details of other points are provided in the extended version of this study.

\subsection{No Change in the Self-identity of EFL learners}

Table 3. Statistical analysis for independent variable no change in the self-identity of the learner

\begin{tabular}{|c|c|c|c|c|c|c|c|c|c|c|}
\hline \multirow[b]{2}{*}{ Variables } & \multirow[b]{2}{*}{ Sections } & \multicolumn{5}{|c|}{ Answers of Sample Members } & \multicolumn{4}{|c|}{ Statistical Indicators } \\
\hline & & 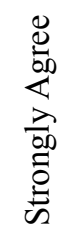 & $\begin{array}{l}\stackrel{8}{0} \\
\stackrel{5}{<}\end{array}$ & $\begin{array}{l}\vec{z} \\
0 \\
\vdots \\
0 \\
0 \\
0 \\
0 \\
0\end{array}$ & 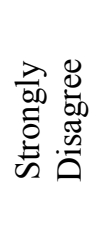 & 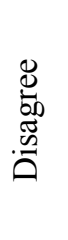 & 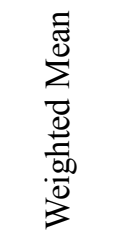 & 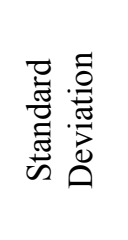 & 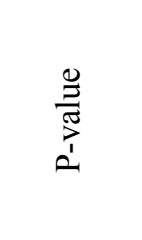 & $\begin{array}{l}\tilde{\tilde{u}} \\
\tilde{\Xi} \\
\tilde{\simeq}\end{array}$ \\
\hline \multirow{2}{*}{ 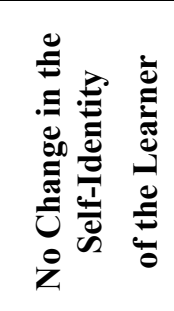 } & $\begin{array}{c}\text { I feel embarrassed } \\
\text { when speaking } \\
\text { English }\end{array}$ & 16 & 35 & 22 & 31 & 46 & 3.3733 & 1.4025 & $<.0001^{*}$ & 4 \\
\hline & $\begin{array}{l}\text { I think learning } \\
\text { English has not } \\
\text { affected my } \\
\text { personality. }\end{array}$ & 9 & 32 & 17 & 33 & 59 & 3.6733 & 1.3436 & $<.0001^{*}$ & 5 \\
\hline
\end{tabular}




\begin{tabular}{|c|c|c|c|c|c|c|c|c|c|}
\hline $\begin{array}{l}\text { I find it very hard to } \\
\text { change my thinking } \\
\text { and behavior just } \\
\text { because I studied } \\
\text { English. }\end{array}$ & 19 & 32 & 41 & 19 & 39 & 3.1800 & 1.3663 & $<.0001^{*}$ & 2 \\
\hline $\begin{array}{l}\text { No matter if I speak } \\
\text { English or Kurdish, I } \\
\text { feel like I am the } \\
\text { same person. }\end{array}$ & 33 & 44 & 19 & 26 & 28 & 2.8133 & 1.4396 & $<.0001^{*}$ & 1 \\
\hline $\begin{array}{l}\text { I do not feel that my } \\
\text { ideas or behaviors } \\
\text { changed as a result of } \\
\text { learning English. }\end{array}$ & 16 & 40 & 30 & 22 & 42 & 3.2267 & 1.3862 & $<.0001^{*}$ & 3 \\
\hline
\end{tabular}

Results of the Table 3 illustrate the following major outcomes:

1). The arithmetic mean and its ranking of the question relating to "No matter if I speak English or Kurdish, I feel like I am the same person" is in the first-place of agreement by the sample members, in which the mean is 2.8133, standard deviation 1.4396, and its $p$-value $=0.0001$ less than $\alpha=0.05$, Indicating that students agree with the content of this question with a moderate degree of the positive direction. In other words, Kurdish learners of English Language do not feel any shortage during their English speaking time.

2). The arithmetic mean and its ranking of the question relating to "I find it very hard to change my thinking and behavior just because I studied English" is in the second-place of agreement by the sample members, in which the mean is 3.1800, standard deviation 1.3663 , and its $p$-value $=0.0001$ less than $\alpha=0.05$, indicating that students disagree with the content of this question with a high degree of the negative direction. That means. English Language really can change the personality and behavior of the learner.

3). The arithmetic mean and its ranking of the question relating to "I do not feel that my ideas or behaviors changed as a result of learning English" is in the third-place of agreement by the sample members, in which the mean is 3.2267 , standard deviation 1.3862, and its $p$-value $=0.0001$ less than $\alpha=0.05$, Indicating that students disagree with the content of this question with a high degree of the negative direction. Therefore, English Language makes learners feel changing in attitudes.

\subsection{Division in the Self-Identity of EFL Learners}

Table 4. Statistical analysis for independent variable division in the self-identity of the learner

\begin{tabular}{|c|c|c|c|c|c|c|c|c|c|c|}
\hline \multirow[b]{2}{*}{ Variables } & \multirow[b]{2}{*}{ Sections } & \multicolumn{5}{|c|}{$\begin{array}{c}\text { Answers of Sample } \\
\text { Members }\end{array}$} & \multicolumn{4}{|c|}{ Statistical Indicators } \\
\hline & & 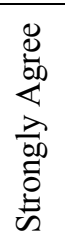 & 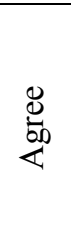 & 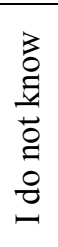 & 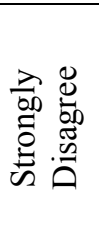 & 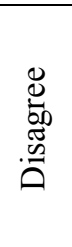 & 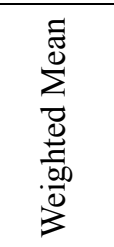 & 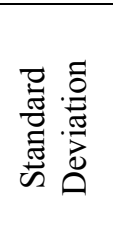 & 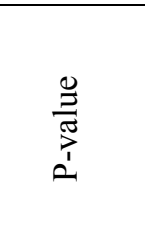 & $\frac{\tilde{y}}{\tilde{I}}$ \\
\hline \multirow{2}{*}{ 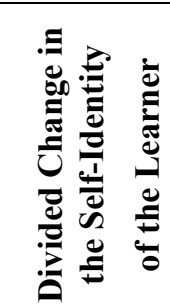 } & $\begin{array}{l}\text { Sometimes speaking in } \\
\text { English makes me have a } \\
\text { different view from most of } \\
\text { the people around me }\end{array}$ & 29 & 63 & 41 & 7 & 10 & 2.3733 & 1.0590 & $<.0001^{*}$ & 2 \\
\hline & $\begin{array}{l}\text { After studying English, I } \\
\text { feel that I should be more } \\
\text { proud of myself as a Kurd }\end{array}$ & 59 & 51 & 14 & 9 & 17 & 2.1600 & 1.3163 & $<.0001^{*}$ & 1 \\
\hline
\end{tabular}




\begin{tabular}{ccccccccccc}
$\begin{array}{c}\text { After studying English } \\
\text { literature, I have a better } \\
\text { understanding of Kurdish } \\
\text { literature }\end{array}$ & 33 & 46 & 27 & 9 & 35 & 2.7800 & 1.4649 & $<.0001^{*}$ & 3 \\
\hline $\begin{array}{c}\text { I feel like I am a kind of } \\
\text { lost in terms of how I think } \\
\text { after learning English }\end{array}$ & 7 & 34 & 46 & 20 & 43 & 3.3867 & 1.2467 & $<.0001^{*}$ & 5 \\
\hline $\begin{array}{c}\text { I get confused between } \\
\text { English and Kurdish } \\
\text { culture when I act with a } \\
\quad \text { foreigner }\end{array}$ & 15 & 39 & 41 & 14 & 41 & 3.1800 & 1.3515 & $<.0001^{*}$ & 4 \\
\hline
\end{tabular}

Results of the Table 4 illustrate the following outcomes

1). The arithmetic mean and its ranking of the question relating to "After studying English, I feel that I should be more proud of myself as a Kurd" is in the first-place of agreement by the sample members, in which the mean is 2.1600, standard deviation 1.3163, and its $p$-value $=0.0001$ less than $\alpha=0.05$, indicating that students agree with the content of this question with a moderate degree of the positive direction. In other words, English Language makes Kurdish learners pleasure and feels proud of English.

2). The arithmetic mean and its ranking of the question relating to "Sometimes speaking in English makes me have a different view from most of the people around me" is in the second-place of agreement by the sample members, in which the mean is 2.3733, standard deviation 1.0590, and its $p$-value $=0.0001$ less than $\alpha=0.05$, Indicating that students agree with the content of this question with a moderate degree of the positive direction. In other words, English Language makes learners think in different direction of the people.

3). The arithmetic mean and its ranking of the question relating to "After studying English literature, I have a better understanding of Kurdish literature" is in the third-place of agreement by the sample members, in which the mean is 2.7800 , standard deviation 1.4649 , and its $p$-value $=0.0001$ less than $\alpha=0.05$, indicating that students agree with the content of this question with a moderate degree of the positive direction. That means, English learners believe that there are some relationships between English and Kurdish Languages.

\section{Conclusions}

Based on the analysis of the collected data, the following conclusions can be reached:

Most Kurdish EFL learners' self-identity changed due to learning English.

Some learners experience a division in their identity after learning English.

Few learners feel no change in their self-identity as a result of learning English.

Learning English has affected the worldview of many Kurdish EFL learners.

\section{References}

Boonchum, P. (2010). A study of self-identity changes and correlation of influential factors of Thai students studying English. Buckingham Journal of Language and Linguistics, 3, 35-55.

Carr-Chellman, D. J., \& Levitan, J. (2016). Adult learning and pragmatic identity theory. Adult Education Research Conference. Retrieved from http://newprairiepress.org/aerc/2016/papers/7

Dascal, M. (1983). Pragmatics and the philosophy of, mind I: Thought in language. Amsterdam: John Benjaminis. https://doi.org/10.1075/pb.iv.1

Erikson, E. H. (1950). Childhood and society. New York: Norton.

Erikson, E. H. (Ed.). (1963). Youth: Change and challenge. New York: Basic books.

Gao, Y., Zhao, Y., Cheng, Y., \& Zhou, Y. (2007). Relationship between English learning motivation types and self-identity changes among Chinese students. TESOL Quarterly, 41(1), 133-155. https://doi.org/10.1002/j.1545-7249.2007.tb00043.x

Goffman, E. (1959). The presentation of self in everyday life. Garden City, NJ: Doubleday Publishing.

Hozhabrossadat, S. (2015). Linguistic Identities: How code-switching and/or code crossing help constructing solidarity or otherness in multilingual societies. International Journal of English and Literature Cult, 3(6), 
194-198.

James, W. (2013). The principles of psychology. Read Books Ltd.

Katzenstein, P. (Ed.). (1996). The culture of national security: Norms and identity in world politics. New York: Columbia University Press.

Lambert, W. E. (1981). Social influences on the child's development of an identity. A Canadian Social Psychology of Ethnic Relations, 57-75.

Lightbown, P. M., \& Spada, N. (2006). How languages are learned. Oxford: Oxford University Press.

Markus, H. (1977). Self-schemas and social processing information about the self. Journal of Personality and Psychology, 35, 63-78. https://doi.org/10.1037/0022-3514.35.2.63

McAdams, D. P. (1995). What do we know when we know a person? Journal of Personality, 63(3), $365-396$. https://doi.org/10.1111/j.1467-6494.1995.tb00500.x

Norton, B. (1997). Language, identity, and the ownership of English. TESOL Quarterly, 31(3), 409-429. https://doi.org/10.2307/3587831

Ochs, E., \& Schieffelin, B. (2008). Language socialization: An historical overview. Encyclopedia of language and education (pp. 2580-2594). US: Springer. https://doi.org/10.1007/978-0-387-30424-3_193

Owens, T. J. (2006). Self and identity. In Handbook of social psychology (pp. 205-232). US: Springer.

Oyserman, D., Bybee, D., Terry, K., \& Hart-Johnson, T. (2004). Possible selves as roadmaps. Journal of Research in Personality, 38(2), 130-149. https://doi.org/10.1016/S0092-6566(03)00057-6

Peck, A. J. (1997). Our Eyes Have Seen Eternity: Memory and Self-Identity Among the She'erith Hapletah. Modern Judaism, 17(1), 57-74. https://doi.org/10.1093/mj/17.1.57

Peirce, B. N. (1995). Social identity, investment, and language learning. TESOL Quarterly, 29(1), 9-31. https://doi.org/10.2307/3587803

Rovira, L. C. (2008). The relationship between language and identity. The use of the home language as a human right of the immigrant. Revista Interdisciplinar da Mobilidade Humana, 16(31), 63-81.

Sacchi, F. A. (2014). Language learning, identity, and agency: A multiple case study of adult Hispanic English language learners. University of Texas at Austin.

Sherif, C. W. (1982). Needed concepts in the study of gender identity. Psychology of Women Quarterly, 6(4), 375-398. https://doi.org/10.1111/j.1471-6402.1982.tb01067.x

Spencer-Oatey, H. (2007). Theories of identity and the analysis of face. Journal of pragmatics, 39(4), $639-656$. https://doi.org/10.1016/j.pragma.2006.12.004

Spolsky, B. (1999). Second-language learning. In J. Fishman (Ed.), Handbook of language and ethnic identity (pp. 181-192). Oxford: Oxford University Press.

Stets, J. E., \& Burke, P. J. (2003). A sociological approach to self and identity. In M. R. Leary, \& J. P. Tangney (Eds.), Handbook of self and identity (pp. 128-152). New York: Guilford Press. https://doi.org/10.1007/978-94-007-6772-0_2

Stets, J. E., \& Serpe, R. T. (2013). Identity theory. In Handbook of social psychology (pp. 31-60). Springer Netherlands.

Stryker, S. (1980). Symbolic interactionism: A social structural version. Benjamin-Cummings Publishing Company.

Swann Jr, W. B. (2005). The self and identity negotiation. Interaction Studies, 6(1), 69-83. https://doi.org/10.1075/is.6.1.06swa

Swann, W. B., \& Bosson. (2010). Self and identity. In S. T. Fiske, D. T. Gilbert, \& G. Lindzey (Eds.), Handbook of social psychology (pp. 589-628). Hoboken, NJ: Wiley.

Tajfel, H., \& Turner, J. C. (1979). An integrative theory of intergroup conflict. The social psychology of intergroup relations, 33(47), 74.

Tbouret-Keller, A. (1998). Language and Identity. In F. Coulmas (Ed.), The handbook of sociolinguistics. Blackwell Publishing.

Teer, S. (2013). An investigation of English learning motivation types and self-identity changes among Thai 
English major students. (Unpublished Doctoral Dissertation). Payap University, Chiang Mai, Thailand.

Tellier, A., \& Roehr-Brackin, K. (2013). The development of language learning aptitude and metalinguistic awareness in primary-school children: A classroom study. (Unpublished Thesis). University of Essex, Colchester, UK.

Tylor, F., Busse, V., Gagova, L., Marsden, E., \& Roosken, B. (2013). Identity in foreign language learning and teaching: Why listening to our students' and teachers' voices really matters. University of York: British Council.

Weinreich, P. (1986). The operationalisation of identity theory in racial and ethnic relations. Theories of race and ethnic relations, 299-320. https://doi.org/10.1017/CBO9780511557828.016

Zare-ee, A., \& Asgari Matin, S. (2014). The relationship betweenEFL learners' self-identity changes, motivation types, and EFL proficiency. Iranian Journal of Applied Language Studies, 6(2), 141-178.

\section{Copyrights}

Copyright for this article is retained by the author(s), with first publication rights granted to the journal.

This is an open-access article distributed under the terms and conditions of the Creative Commons Attribution license (http://creativecommons.org/licenses/by/4.0/). 